مقايسه اثربخشى درمان مبتنى بر شفقت و و اقعيت درمانى بر خودكار آددى بيمار ان مبتلا به مالتيّيل اسكلروزيس

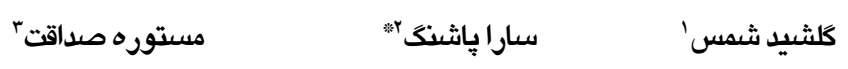

I. ا. كروه روانشناسى، واحد بينالملل كيش، دانشكاه آزاد اسلامى، جزيره كيش، ايران.

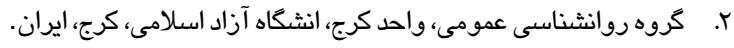

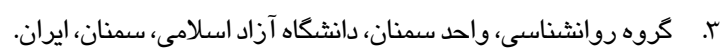

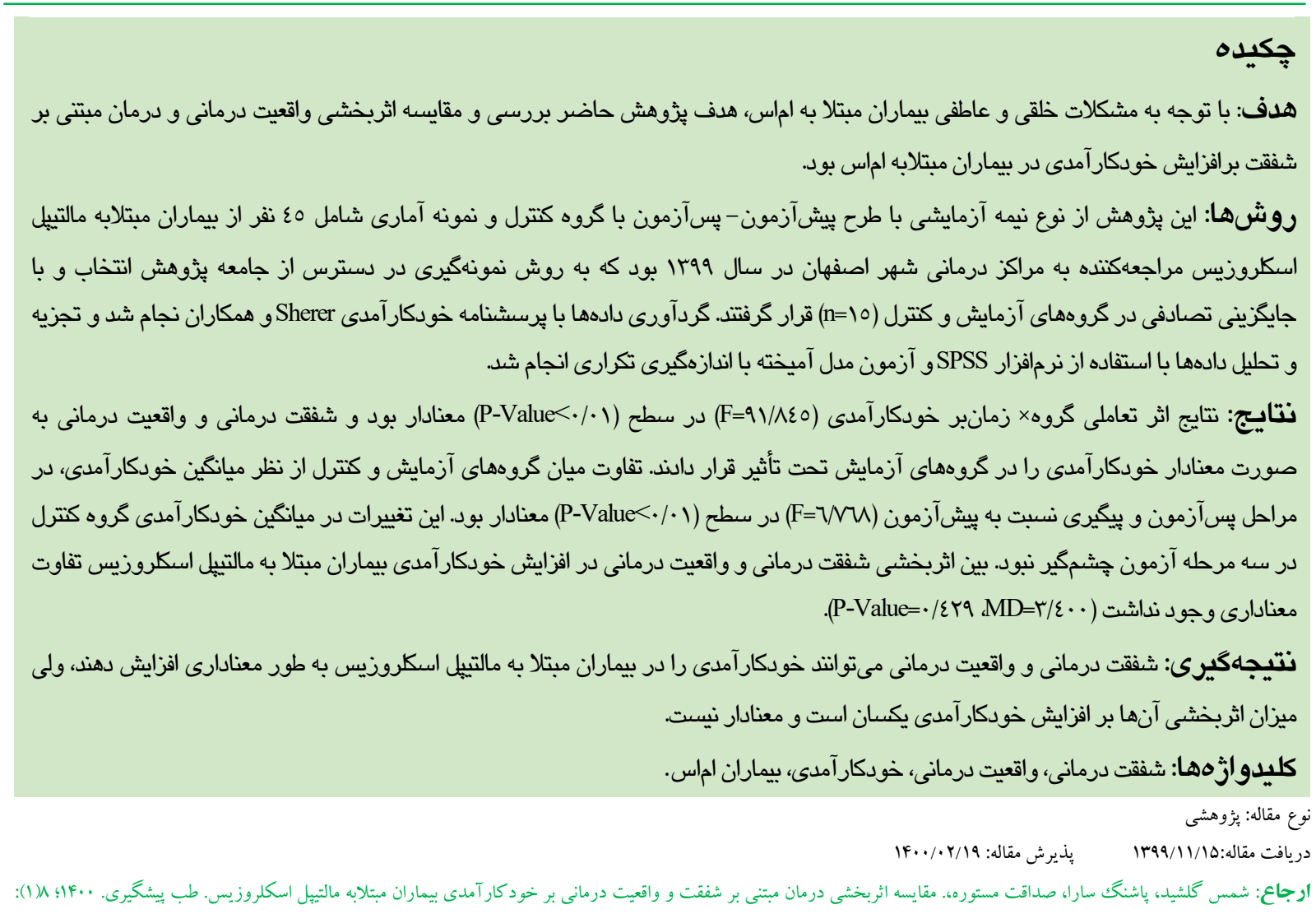

$. v \cdot-\wedge$.

الماس از خود دلسوزى بالاترى برخوردارند و استرس باعث ايجاد رابطه مثبت بين خود- دلسوزى و بهزيستى روانى اين

$$
\text { افراد مىشود (0، ع). }
$$

درزمينه درمانهاى روانشناختى كه در بهبود علائم بيمارى

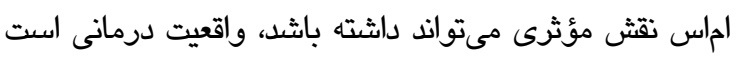
(7). واقعيت درمانى مجموعهاى از روشها براى كمك به افراد به منظور حركت از رفتارهاى ناكارآمد به رفتارهاى كارآمد، از

\section{مقدمه}

بيمارى مالتيِل اسكلروزيس منجر به ناتوانى و ايجاد انواع اختلالهاى حسى و حركنى در فرد بيمار مىشود و با مشكلاتى

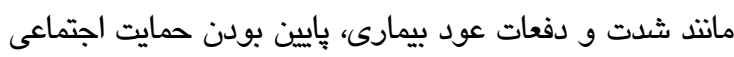

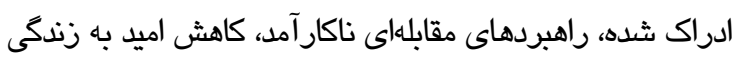
و مشكالات عاطفى و اقتصادى، و اختلالهاى روانشناختى

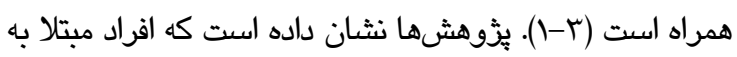


اجتماعى بندورا و يكى از متغيرهاى شخصيت است كه نقش بسيار مهمى در برخورد فرد با مسائل زندكى دارد (·r). همجنين بزوهشها نثان داده است كه باورهاى مربوط به كارايى، به توانايىهاى خود فرد براى اجراى برخى از اقدامات يا وظايف خاص اشاره دارد، و ييشبينىكتده قابل توجهى از تلاش و

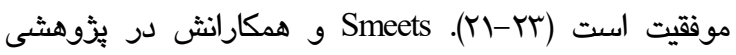
دريافتت كه آموزش درمان متمركز بر شفقت به افزايش معنادار خوشبينى و خودكارآمدى و كاهش معنادار نثخوار فكرى در

$$
\text { دانثجويان شده است (ع)). }
$$

با توجه به ويزگكهاى درمان مبتى بر شفقت شامل

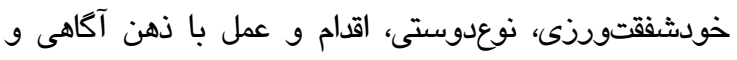
همجنين تمركز اين درمان بر احساس امنيت و نتايج بيشينى نثده و همجنين ويزگكى اصلى واقعيت درمانى كه شامل تمركز بر نيازها از طريق منطق و عقالنيت، توسعه نيازهاى اساسى با انتخاب بهتر و آكاهانه، تمركز بر فعاليت، احساس، فيزيولوذى و تقكر است (0r، ع)). بنابراين بزوهش حاضر با هدف به كاركيرى اين رويكردهاى درمانى و مقايسه ايجاد تغييرات مثبت در افزايش خودكار آمدى بيماران اماس انجام

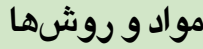

اين بِّوهش از نوع نيمهآزمايشى با طرح بيشآزمون-

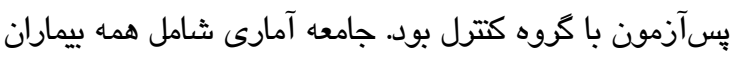
مبتالا به احاس مراجعكتنده به مركز تحقيقاتى، آموزثىى و درمانى

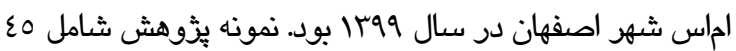
نفر از ييماران مبتلا به الماس بود كه به روش در دسترس انتخاب و به روش تصادفى قرعهكثى در كروههاى آزمايش و كتترل قرار كرفتت. ملاكهاى ورود شامل داشتن حداقل سواد خواندن و نوشتن، حداقل يك سال تحت درمان بودن، عدم اعتياد و ملاكهاى خروج شامل ابتالى همزمان به بيمارىهاى مزمن ديكر، دو جلسئ غييت متوالى يا سه جلسأ غيرمتوالى، عدم انجام دقيق تكاليف و
انتخابهاى مخرب به اتتخابهاى سازنده و از همه مهمتر از سبك زندكى ناخوشنود به سبك زندكى خشنود است (V). اين دويكرد براساس توانايى شركتكتنكان در تمركز بر نيازهايثان از طريق فرآيندهاى عقلانى و منطقى تأكيد دارد. از ديدكاه كالاسر افراد تصوراتى را جهت ارضاى نيازهاى ذاتى خود در ذهنثان خلق مىكتد (^). واقعيت درمانى مىتواند بر كاهش استرس، اضطراب و مشكلات روانشناختى بيماران مبتلا

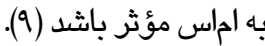
شفقت درمانى نيز توجه درمانكران نوين را براى

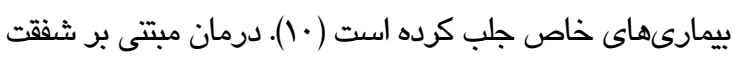
با هدف كاهش درد، رنج، نكرانى و افسردكى ايجاد شده است (1)(.) دو هدف اساسى در رويكرد متمركز بر شفقت كاهش خصومت عليه خود و توسعأ توانايىهاى فرد جهت ايجاد احساس خود اطمينانى، مهريانى و خود تسكينى در برابر احساس تهديد شدكى، كاهش علائم منفى روانشناختى، ايجاد شاخصهاى خودشفقتورزى، نوعدوستى، عمل كردن با ذهن آكاهى در بيماران مبتلابه سرطان، و همجنين مديريت موقعيتهاى منفى و پاسخ مؤثر به وقايع ناخوشايند حاكى از

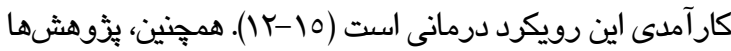
نثان دادند كه بين خود دلسوزى و كيفيت زندكى رابطةٌ مثبت وجود دارد (17). در يُّوهشى اثربخشى درمان متمركز بر شفقت بر افزايش سلامت روان بيماران الماس و بر تابآورى زنان مبتلا به الماس نثان داده شده است (IVIN). از ميان مهرترين عوامل در تبيين رفتارها، فعاليتها و كتترل كاركرد انسانى، هيجكام مؤثرتر از خودكارآمدى نيست و باورهاى خودكارآمدى افراد نقش مهمى در جِكونكى نكرش هُش آنها به شرايط مختلف و جِكَّنَى احساس، فكر و رفتار دارند.

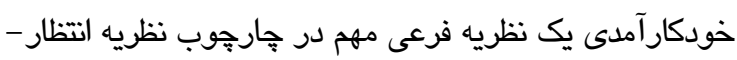
ارزش در بحث از انكيزش است (9). يزوهشها نثان دادهاند كه باورهاى خودكارآمدى به عنوان مهمترين تعيينكتده انكيزش، عاطفه، تقكر و عمل هر فرد، از سازههاى مهر در نظريه شناختى 
و كرويت موخلى به عنوان بيشفرضهاى تحليل واريانس با اندازمكيرى تكرارى استفاده شد. در زمينه ملاحظات اخلاقى يذوهش، ضمن ارائه توضيح كافى درباره هدف، اهميت، روش، مدت و شرايط اجراى مداخله بذوهشى و ارزيابىها به شركتكتنكان، از آنها رضايتنامه

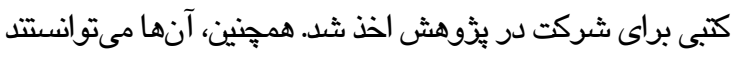
در هر مرحله از يُزوهش، در صورت علم رضايت از ادامه شركت در تحقيق انصراف دهن. در راستاى سياسكزارى از شركت اعضاى كروه كترل در بذوهش، ضمن تعهد درباره آكاهى آنها از نتايج يزوهش، هدايابى نيز براى آنها در نظر كرفته شد. برسشنامة خودكارآمدى شرر و همكاران در سال raA 19 ساخته شده است و داراى r ماده است. IV ماده از اين برسشنامه به خودكارآمدى عمومى و 7 ماده ديكر آن به تجربيات خودكارآمدى در موقعيتهاى اجتماعى اختصاص دارد. آزمودنى براساس مقياس 0 درجهاى ليكرت به سؤالهاى برسشنامه ياسخ

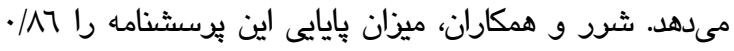
كزارش كردند. در بزّوهش براتى /M7· و در بِّوهش نجفى و

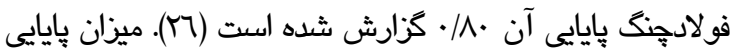
اين بِرسشنامه در بِّوهش حاضر نيز به روش آلفاى كرونباخ

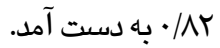

تمرينهاى منزل طى سه جلسئ متوالى يا غيرمتوالى، استقاده از داروهاى روانكردان و روانيزشكى در حين انجام يزوهش بود. بذوهشكر مطمئن شد كه آزمودنىها قبلاً و همجنين در حين اجراى جلسات درمان تحت هيجكونه آموزن يا روند درمانى مشابه قرار نكرفتهاند. بِ ازآن كه آزمودنىها به روش كاملاً تصادفى در سه كروه جايكزين شدند، هر سه كروه برسشنامها خودكارآمدى Sherer و همكارانش را تكميل كردند (مرطئ

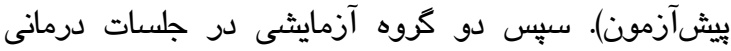
مربوطه (كروه آزمايشى ا: درمان متمركز بر شفقت؛ كروه آزمايشى ז: واقعيت درمانى كالاسر) شركت نمودند و در مورد

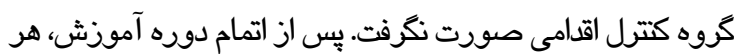

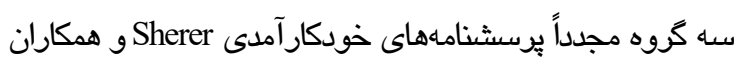
را تكميل كردند (يس آزمون). در نهايت آزمون بيكيرى نيز با فاصله يك ماه بِ از اجراى بِ آزمون، دوياره بر روى كروهها انجام و

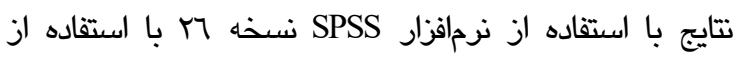
آمارههاى ميانكين و انحراف معيار در بخش توصيفى و مدل تحليل آميخته با اندازهكيرى مكرر در بخش استباطى انجام شد. همجنين آزمون شاييرو - ويلك براى فرض نرمال بودن دادها،

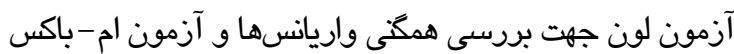

(YV) محتواى جلسات درمان متمركز بر شفقت مبتنى بر طرح درمانى كيلبرت

\begin{tabular}{|c|c|c|c|c|}
\hline رفتار مورد انتظار & تمرين خانكى & محتوا & اهداف & جلسه \\
\hline آشنايى كلى با خود & تمرين تنفس آرامبخش & آشنايى اوليه، برقرارى ارتباط، آشنايى با مفهوم كلى شفقت به خود و & 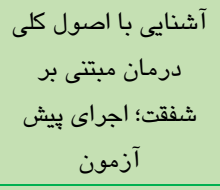 & 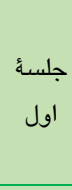 \\
\hline مقابله با افكار خود & 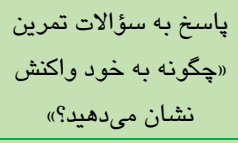 & 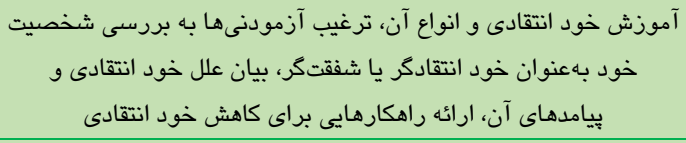 & آشكار خود انتقادكر آشتار و & 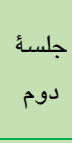 \\
\hline بذ بذش اشتبدن خود & ت اشتباهات دفترجه و و ثبت & 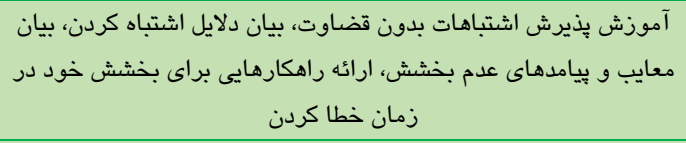 & بذيرش اشتباهات و & 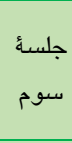 \\
\hline إسرورش حس اشتراكات داسات در مقابل & درباره شفقت به حالى دوزانه & 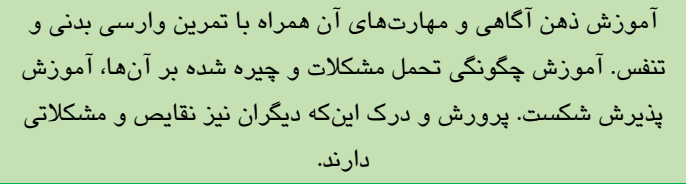 & شرك و توانايى تحمل & جلسو \\
\hline
\end{tabular}




\begin{tabular}{|c|c|c|c|c|}
\hline رشد احساس خود & تمرين قدردانى از خود و & و آموزش خون ارزشس بايين، آموزش و مزاياى آن، بيان معايب خود ارزشاى تقويت حس خود ارزشمندى بايين & قدردانى از خود & جلنجم \\
\hline برورش افكار شفقت & تمرين تصويريردازى & 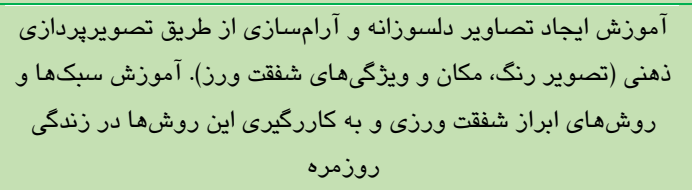 & ايجاد احساسات & ششم \\
\hline برورش افكار شفقت & ت ت مرين نوشتن عبارات & 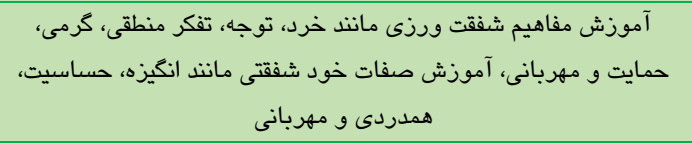 & آشنايى با رفتار & 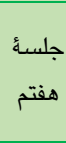 \\
\hline آكاهى از افكار و & تمرين صندلى خالى كشتانت & 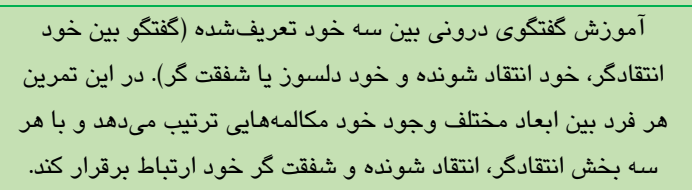 & شناسايى احساسات & 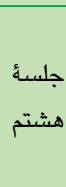 \\
\hline بذيرش خود & تمرين نوشتن نامـه & 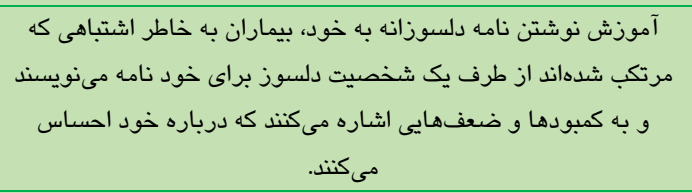 & درك و يذيرش خود & نهم \\
\hline 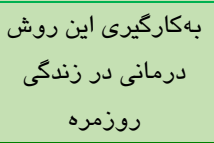 & مرور تمرينات كذشته & دريافت بازخورد از اعضاى كروه درباره اصول آموزش دادهده، مرور & مرور مباحث آموزش آشداء اجراى بس- & دهم \\
\hline
\end{tabular}

محتواى جلسه هاى واقعيت درمانى (Y^)

ايجاد روحية خودشناسى و خودباورى با توجه به استعدادها و توانايىهاى فردى و

برقرارى رابطة حسنه و دركيرى عاطفى بين رهبر و ساير اعضا

\section{آشنايى اعضاى كروه با يكديكر و معرفى و

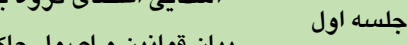

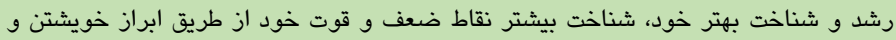

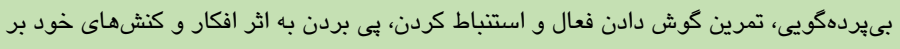

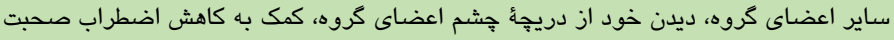
جلسه دوم افزايش شناخت و آكاهى هر عضو از خود

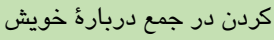

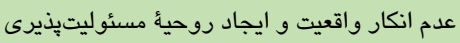

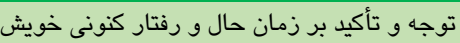

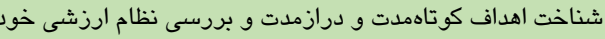

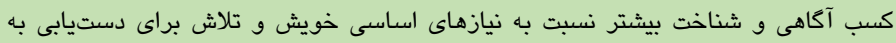

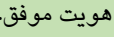
شناخت نشانهها و موقعيتهاى يأس آور، بررسى تفكر خودكار افراد در موقعيتهاى ناميدكنتده،

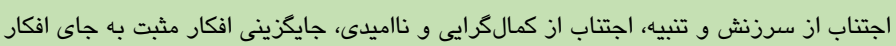

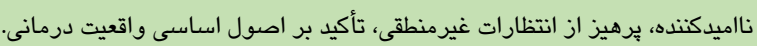

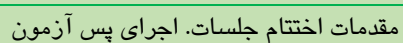

تشخيص نشانهایى يأس و ناميدى و كسب برخى

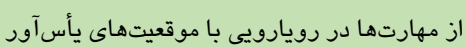
جلسه هفتم جلسه هشتر

$$
\text { تشكر و اختتام }
$$$$
\text { جلسه سوم }
$$
جلسـه جهارم جلسه بنجم جلسه ششم
درمانى) به ترتيب • • بره و اس/ه ، در كروه آزمايش Y (واقعيت درمانى) به ترتيب س/س و 199 و و در كروه كتترل به ترتيب

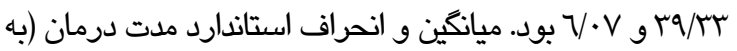
سال) براى شركتكتنكان در كروه آزمايش ا (شفقت درمانى) به ترتيب س/O/ و ع/V/ ، در كروه آزمايش Y (واقعيت درمانى) به

\section{يافتهها}

در اين بثوهش به منظور تجزيه و تحليل دادها از روش تحليل مدل آميخته همراه با اندازهيرى مكرر استفاده شد. تحليل ويزٔحىهاى جمعيت شناختى شركت كنتدكان نشان داد كه ميانكَين و انحراف استاندارد سن آنها در كروه آزمايش ا (شفقت 
دادهاى مربوط به مؤلفه خودكارآمدى در كرودهاى آزمايش و كتترل در سه مرطه اندازكيرى نرمال است. همجنين تتايج آزمون لون در ارزيابى مفروضه همكنى واريانسهاى خطاى مؤلفه خودكارآمدى نثان داد كه تقاوت واريانس خطاى نمرات مربوط به آن در سه كروه و در سه مرحه آزمون معنادار نبوده و بنابراين مفروضه مزبور در بين دادها برقرار بود. منطبق بر جدول ז، تتايج نثان داد كه مفروضه همكنى ماتريسهاى كوواريانس متغيرهاى وابسته براى متغير

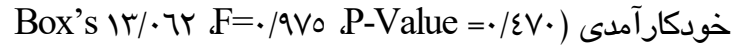
برقرار است. همجنين اثر تعاملى كروه× زمانبر متغير خودكارآمدى (ع-Value=./..

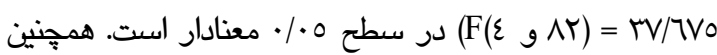
نتايج آزمون كرويت موخلى نثان داد كه ارزث مجذور كاى

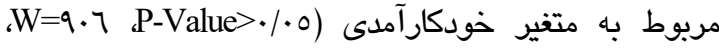
0. است كه مفروضه كرويت براى آن متغير برقرار است.
ترتيب كو/1 و M/• و در كروه كترل به ترتيب 7/ع/ و ع/V• بود. ميزان تحصيلات ع نفر از شركتكتدكان در كروه آزمايش | (شفقت درمانى) دييلم و فوقدييلم، 7 نفر ليسانس و 0 نقر بالاتر از ليسانس بود. ميزان تحصيلات V نفر از شركتكتنكان در كروه آزمايش Y (واقعيت درمانى) دييلم و فوقدييلم، V نقر ليسانس و ا نقر بالاتر از ليسانس بود. كروه كترل نيز ميزان تحصيلات ع نفر دييلم و فوقدييلم، 9 نفر ليسانس و r نفر بالاتر

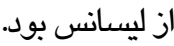

جدول ا - ميانخين (انحراف استاندارد) خودكار آمدى در كروههاى آزمايش و كنترل

\begin{tabular}{|c|c|c|c|c|}
\hline بيكيرى & پِآزمون & ييشآزمون & كروه & \\
\hline $\begin{array}{l}\varepsilon 0 / \varepsilon . \\
(V / q)\end{array}$ & $\begin{array}{l}\varepsilon \varepsilon / T . \\
(V / 01)\end{array}$ & $\begin{array}{l}\text { rV/or } \\
(0 / 70)\end{array}$ & شفقت درمانى & \\
\hline $\begin{array}{l}\varepsilon N / \varepsilon . \\
(\mathrm{T} / \mathrm{V} \cdot)\end{array}$ & $\begin{array}{l}\varepsilon V / \Lambda T \\
(V / \Lambda Y)\end{array}$ & $\begin{array}{l}M / \cdot 7 \\
(O N Y)\end{array}$ & دراقعيت & خودكارآمدى \\
\hline $\begin{array}{l}r \varepsilon / r r \\
(0 / .0)\end{array}$ & $\begin{array}{l}\Gamma / 9 Y \\
(0 / 0 \Lambda)\end{array}$ & $\begin{array}{l}r \varepsilon / \cdot 7 \\
(0 / \wedge \varepsilon)\end{array}$ & كتترل & \\
\hline
\end{tabular}

در اين بُزوهش ارزيابى مقادير شايِيرو- ويلك جهت بررسى مفروضه نرمال بودن توزيع دادهها نشان داد كه توزيع

جدول r- نتايج آزمون مفروضه برابرى ماتريسهاى واريانس - كوواريانس و تحليل جند متغيرى

\begin{tabular}{|c|c|c|c|c|c|c|c|c|}
\hline \multicolumn{5}{|c|}{ آزمون جند متغيرى } & \multicolumn{3}{|c|}{ برابرى ماتريس واريانس كوواريانسها } & \multirow{2}{*}{ 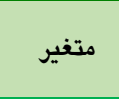 } \\
\hline$\eta^{r}$ & $\mathrm{P}$ & Df & $\mathrm{F}$ & و ويلكز & $\mathrm{P}$ & $\mathrm{F}$ & M.Box & \\
\hline$\cdot / \neg \varepsilon \wedge$ & $\% 1$ & $\Lambda \varepsilon, \varepsilon$ & rV/TVO & $\cdot / 1 r \varepsilon$ & $\cdot / \varepsilon \vee$ &.$/ 9 \vee 0$ & $\mid r / \cdot T r$ & خو دكار آمدى \\
\hline
\end{tabular}

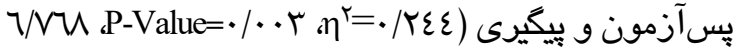
(F() در سطح I) • • • • معنادار است. اين در حالى كه ميزان اين تغييرات در كروه كترل جڤشمَير نيست. بدين ترتيب مشخص شد كه شفقت درمانى و واقعيت درمانى خودكارآمدى را در بيماران مبتلا به مالتيّل اسكلروزيس به طور معنادار افزايش مىدهند. در تأييد اين مطلب نمودار ا نشان مىدهد كه در كروههاى آزمايش (شفقت درمانى و واقعيت درمانى) نسبت به كروه كتترل ميانكين نمره
جدول ب نشان مىدهد اثر تعاملى كروه× زمانبر متغير خودكارآمدى (ع و ع(F) در سطح (P-Value معنادار است. به عبارت ديكر اجراى متغير مستقل (شفقت درمانى و واقعيت درمانى) به صورت معنادار خودكار آمدى را در كروههاى آزمايش تحت تأثير قرار داده است. همجِنين نتايج آزمون يين كروهى حاكى از آن است كه تفاوت ميان كُوههاى آزمايش و كترل از نظر ميانكين خودكارآمدى، در مراحل 
خودكارآمدى در مراحل بِ آزمون و بيىيرى در مقايسه با مرحله بِيشآزمون افزايش يافته است. جدول r- نتايج تحليل آميخته اندازهيرى تكرارى و آزمون بين كروهى نمرههاى خودكار آمدى در كروههاى آزمايش و كنترل

\begin{tabular}{|c|c|c|c|c|c|c|c|}
\hline$\eta^{r}$ & $\mathbf{P}^{\prime}$ & $\mathbf{F}$ & ميانكين مجذورات & درجه آزادى & مجموع مجذورات & منبع تغييرات & \\
\hline$\cdot / 199$ & $\% \cdot \cdot 1$ & $r V Y / 197$ & $19 V V / 907$ & $r$ & $r 900 / 911$ & زمان & درون \\
\hline$\cdot / \wedge \mid \varepsilon$ & $\% \cdot 1$ & $91 / \wedge \varepsilon 0$ & $\varepsilon N / \cdot \wedge q$ & $\varepsilon$ & $190 r / r 07$ & تعامل (كروه * زمان) & كروهى \\
\hline- & - & - & $0 / \pi I \varepsilon$ & $\wedge \varepsilon$ & $\varepsilon \varepsilon 7 / \varepsilon \ldots$ & خطا & \\
\hline$\cdot / T \varepsilon \varepsilon$ & $/ \cdot r$ & \urcorner$/ \vee\urcorner \wedge$ & $v q . / \cdot v 7$ & 1 & $101 \cdot / I r T$ & كروه & بين \\
\hline- & - & - & $117 / V r r$ & $\varepsilon r$ & $\varepsilon q \cdot r / \wedge .$. & خطا & كروهى \\
\hline
\end{tabular}

بزّوهش حاضر با هدف مقايسه اثربخشى واقعيت درمانى و

درمان متمركز بر شفقت بر افزايش خودكارآدىى بيماران مبتلا به مالتيِل اسكلروزيس انجام شد. نتايج حاكى از آن بود كه مداخله شفقتدرمانى و واقعيتدرمانى به صورت معنادار خودكارآمدى را در كروههاى آزمايش تحت تأثير قرار داده است. همجنين نتايج آزمون بين كروهى نشان داد كه تقاوت ميان كروههاى آزمايش و كترل از نظر ميانكين خودكارآمدى، در مراحل بيشآزمون، پِسآزمون و يِيكيرى معنادار است و شفقت درمانى و واقعيت درمانى توانستهاند ميزان خودكار آددى را در بيماران مبتلا به مالتيِل اسكلروزيس افزايش دهن. همجنين، نتايج حاكى از آن بود كه ميزان اثربخشى دو رويكرد واقعيت درمانى و شفقت درمانى در شركتكنتكان كروههاى آزمايش به يك ميزان بوده است و در اين زمينه بين اين دو رويكرد درمانى تفاوت معنادارى وجود ندارد. نتايج اين يثوهش همسو با نتايج Nery- يخوهشاى سليمى و همكاران، قطور و همكاران، Gurwit در تبيين اين يافته مىتوان كَت جون سيستم تهديد و محافظت از خود در بيماران مبتلا به اماس به واسطه اختلالهاى روانشناختى از جمله افسردگى و اضطراب به نوعى بِركارى شديد دجار است، لذا در نتيجه آن سطوح استرس و نكرانى در اين افراد بالا خواهد بود كه همين امر منجر به بايين آمدن سطوح خودكارآمدى در آنها مىشود؛ از طرف ديكر در بيماران اماس سيستم رضايت و تسكين نيز سطح رشديافتخى پايينترى دارد

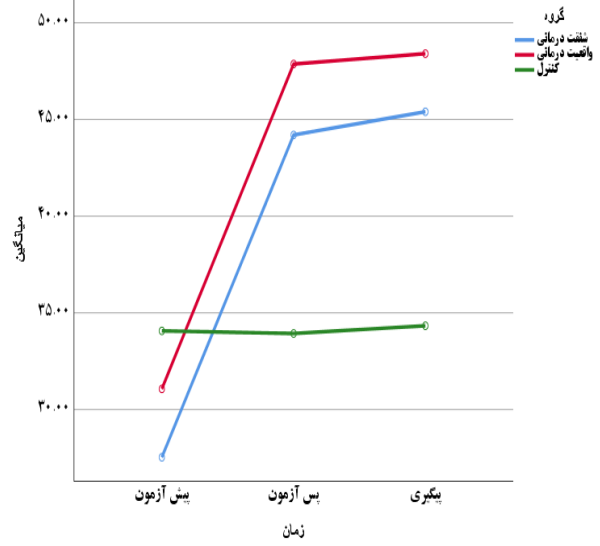

نمودار 1-مقايسه ميانكين خودكار آمدى در كروه شفقت درمانى، واتعيت

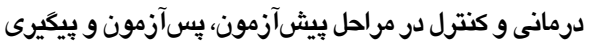

منطبق بر جدول ع مقايسه دو به دو ميانغينها نثان داد بين اندازه اثربخشى شفقت درمانى و واقعيت درمانى در افزايش خودكارآمدى بيماران مبتلابه مالتيل اسكلروزيس تقاوت

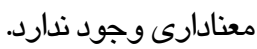

جدول ץ- نتايج مقايسه يك به يك ميانكين كروهها براى متغير استرس

\begin{tabular}{|c|c|c|c|c|c|}
\hline \multirow{2}{*}{ معنادارى } & \multirow{2}{*}{ ختاندارد } & \multirow{2}{*}{ ميانكين } & \multicolumn{2}{|c|}{ كروه ها } & \multirow{2}{*}{ متغيرها } \\
\hline & & & $(\mathrm{J})$ & (I) & \\
\hline.$/ \cdot 1$ & $T / T V$ & $\varepsilon / 9 T r$ & كتترل & شفقت درمانى & \\
\hline$\% r$ & $T / T V$ & N/rTr & كتترل & واقعيت درمانى & خودكار آمدى \\
\hline ./हrq & $T / T V$ & $r / \varepsilon$. & درمانى & شفقت درمانى & \\
\hline
\end{tabular}

\section{بحث و نتيجهيرى}


خود و توسعة توانايىهاى فرد جهت ايجاد احساس خود اطمينانى، مهربانى و خودتسكينى از اهداف اساسى درمان متمركز بر شفقت بود كه توانسته است به عنوان بپادزهرى در برابر احساس بىكفايتى و فثار روانى ناشى از آن در بيماران

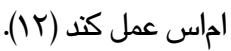
درزمينه اثريخشى واقعيت درمانى بر افزايش خودكارآمدى در بيماران احاس نيز مىتوان كفت با آموزثهاى اين رويكرد به بيماران اماس آنها ياد كرفتتد كه بر واقعيت، قبول مسئوليت و شناخت امور درست و نادرست و ارتباط آنها با زندكى روزمره خود متمركز شوند. بدين ترتيب آنها با قبول رفتار مسئولانه در خود توانستهاند از رفتارهاى غيرمسئولانه كه زمينهساز شكست و نوسان خلق و ايجاد فشار روانى ناشى از آن مىشود، برهيز كتد. همجنين كاربرد واقعيت درمانى باعث شده است افراد از طريق خودارزيابى، تمركز را از رفتارى كه خارج از كتترل آنهاست برداشته و بر جنبهایى قابل كتترل تمركز كتن تا از طريق كنتكوى مثبت درونى، هيجانهاى منفى و ناكار آمد در آنها كاهش يابد و بر توانمندىهاى خود تأكيد كتن. در تتيجه فرد توانسته است حس توانندى را در خود توسعه دهد. بدين ترتيب، واقعيت درمانى ككك مىكند تا افراد متوجه شوند كه مىتواتتد بر زندكى خود كتترل داشته باشند و از كتترل بيرونى رهايى يابن و با اتتخابهاى مناسب مسئوليت رفتارشان را بر عهده بكيرند كه به نوبه خود باعث توانمندى و اعتماد به نفس و افزايش حس خودكارآمدى در آنان مىشود (V). واقعيت درمانى به افراد مبتلا به الحاس آموخته است كه بتواتت در برابر سختىها و مشكلات بايستن و مسايل بيش آمده را به كردن ديكران نينازند و از كتترل درونى به جاى كتترل بيرونى استفاده

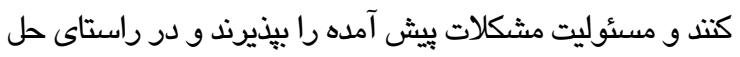
آن يا كنار آمدن با بيمارى و مشكلات مربوط به آن تمام توان خود را به كار بكيرند. اين فرآين ككك مىكند افراد به جاى مكانيسم جنك و كريز در برابر مشكلات، بر حل آن تمركز كرده و در تتيجه تمركز بر حل مشكلات، مسئوليتيذيرى در آنان
و فرصت كافى براى تحول اين سيستم را هركز نداشتهاند. درمان متمركز بر شفقت همانت فيزيوترابى ذهن براى اين افراد عمل مىكن. بدين ترتيب كه با تحريك سيستم تسكينبخشى، زمينه تحول آن رافراهم مىكند و با تحول اين سيستم تابآورى فرد در برابر مشكلات بيمارى بالا مىرود و باعث بهبود عزتنفس و بيشرفت خودكارآمدى فرد مىشود (9). همجنين درمان مبتى بر شفقت بر حساسيت به وجود رنج در خود و ديكران، مهربان بودن با خود و داثتن توجه مهربانانه با خود، استدلال مهربانانه به جاى استلال منطقى و صحبت با خود با جملات مثبت به جاى جملات انتادى و خود سرزنثى و در مجموع پذيرفتن رنجى كه بر فرد وارد است، همجنين برقرارى

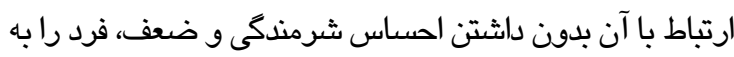
رفتار مهريانانه مىرساند و در نتيجه اين امر مىتواند مسبب ايجاد احساس بهتر در مورد كليت خود وحس خودكارآدىى شود؛ بنابراين، در تبيين تأثير درمان مبتى بر شفقت بر بر برد

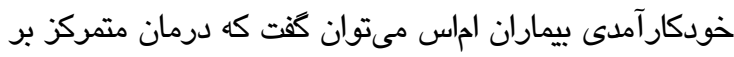
شفقت به دنبال شفاف سازى اجزاء اصلى شفقت متل حساسيت توام با توجه، انكيزه مراقبت، همدردى، همدلى، تحمل بريشانى و داشتن ديدكاه غير قضاوتى نسبت به خود است و درمان متمركز بر شفقت بر آزادسازى افراد از اين تلههاى ذهنى تأكيد مىكث. درمان متمركز بر شفقت بر آموزش تتفس، ذهن آكاهى و براني

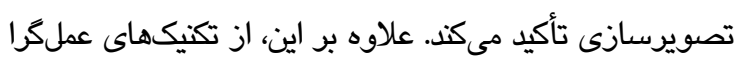
جون تمرين عمل كردن و تصويرسازى خود بهعنوان يك فرد مهربان مورد استفاده قراد مىگيرد تا به افراد در ساختن هويتى با ويزگىهاى شفقتآميز يارى رساند. به دنبال آن اين "خود" جديد به عنوان پايكاهى امن براى مواجها با مشكلات و رنجها تبديل مىشود كه زمينهاز تحول در وجود فرد و غلبه بر احساس بىكفايتى و در نتيجه ارتقاء حس خودكارآمدى در فرد مىشود. به طورى كه شفقت باعث تقويت شجاعت افراد در مواجهه با جنبهاى دشوار و تاريك ذهن و منجر به احساس مثبت راجع به خود مىشود. همجنين كاهش خصومت به سمت 


\section{تشكر و قدردانى}

مقاله حاضر بركرفته از بِاياننامه دكتراى رشته روانشناسى سلامت دانثكاه آزاد اسلامى واحد بينالملى كيش اسـت. بـدين وسيله از تمامى كسانى كه مـا را در انجـام ايـن يـزَوهش يـارى رساندن، تقدير و تثكر به عمل مى آيد.

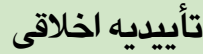

اين مقاله بركرفته از بايانامه دكتراى روانشناسى سلامت دانشكاه بينالملل كيش مورخ ع/r/T99/ و جلسه كميته اخلاق دانشكاه علوم بزشكى هرمزكان با كـ اخلاق IR.HUMS.REC.1399.182

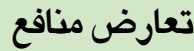

بنا به اظهارات نويسنكان اين مقاله، هيجكونه تعارض منافعى ندارد.

\section{سهم نويسندكان}

كلثيد شمس (نويسنده اول) مفهومبردازى، طراحى مطالعه، نكارش و جمعآورى دادها . م درصد؛ سارا بِاشنگ (نويسنده دوم و مسئول) مفهوميردازى، طراحى مطالعه و ويرايش متن درصد؛ مستوره صداقت (نويسنده سوم) مفهومبردازى، طراحى مطالعه و ويرايش متن OT درصد.

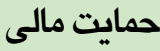

اين مقاله از طرف هيجكونه نهاد يا مؤسسهایى حمايت مالى نثده و تمام منابع مالى آن از طرف نويسنده اول تأمين شده

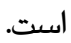

افزايش يابد كه همين امر منجر به افزايش حس خودكار آمدى در

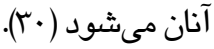

در مجموع مىتوان كفت كه اختال در كنار آمدن با بيمارىهايى ماتت مالتييل اسكلروزيس اغلب منجر به بروز مشكلات خلقى و احساس خود سرزنثى در اين افراد مىشود كه اين امر به علت از بين رفتن بافت ميلين در بعضى قسمتهاى مغز است؛ بنابراين مداخلات مبتى بر رواندرمانى مىتواند براى بيماران مبتلا به اماس مفيد باشد؛ زيرا ييماران با ييان نكرانىهاو اضطرابهاى خود به متخصصين روان درمانى، مىتوانت كمكها و راهنمايى لازم را براى نحوه فكر كردن يا تغيير در رفتارشان طراحى كتد تا از طريق آن توانايى لازم را براى درد رهايى از مشكلات روحى و هيجان مرتبط با اين بيمارى در خود برورش بدهن. تتايج اين بزّوهش خود شاهدى بر اين مدعاست كه درمانهايى مانت واقعيت درمانى و شفقت درمانى مىتواتت در كاهش علائم و نثانههاى اين بيماران به خوبى عمل كتن. در تتيج، بيشنهاد مىشود كه اثربخشى ساير رويكردهاى روان درمانى نيز بر بهبود سلامت روانى اين افراد به طور كلى و بر بهبود نثانها و اختلالهاى همآيذ به اين بيمارى ماتت افسردكى، اضطراب، استرس، تحريكيذيرى و برخاشكرى، خستكى و ضعف و احساس نااميدى و بىكفايتى به صورت

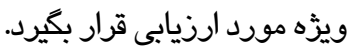
از جمله محدوديتهاى اين بزّوهش افت آزمودنىها به دليل شيوع ويروس كرونا و ترس شركتكتدكان در بِّوهش براى حضور منظم در جلسات كروهى بود كه در نهايت بِّوهشكر تتوانست براى هر كروه بيش از 10 نفر نمونه در اختيار داشته باشد؛ بنابراين، بيشنهاد مىشود نمونهاى مشابه اين بِّوهش

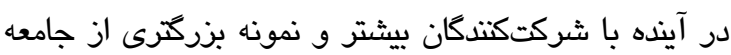
بيماران الماس در قالب رويكرد مشاوره كَروهى انجام شود.

\section{References}


1. Sakhaei S, Motaarefi H, Zinalpoor S, Sadagheyani HE. Functional evaluation of multiple sclerosis patients in Khoy (IRAN). Open Public Health J. 2018; 11(1):37-43. DOI: $10.2174 / 1874944501811010037$

2. Bogosian A, Moss-Morris R, Hadwin J. Psychosocial adjustment in children and adolescents with a parent with multiple sclerosis: A systematic review. Clin Rehabil. 2010; 24(9):789-801. DOI: $10.1177 / 0269215510367982$.

3. Jahanbakhsian N, Zahrakar K, Davarniya R. A Study on the effectiveness of caregivers' group supportive-training intervention on the mental health of MS patients. RJMS. 2016; 23(144):1929. [Persian]

4. Aydin A. A comparison of the alexithymia, selfcompassion and humour characteristics of the parents with mentally disabled and autistic children. Procedia Soc Behav Sci. 2015; 174:720-9. DOI: 10.1016/j.sbspro.2015.01.607

5. Moreira H, Gouveia MJ, Carona C, Silva N, Canavarro MC. Maternal attachment and children's quality of life: The mediating role of self-compassion and parenting stress. J Child Fam Stud. 2015; 24(8):2332-44. DOI: 10.1007/s10826-014-0036-Z

6. Abdolahi MN, Shafiabadi A, Behboudi M. The study of effectiveness of group counseling based on reality therapy on increasing of self esteem in mothers of children with cerebral palsy. RBS. 2014; 12(3):360-8. [Persian]

7. Wubbolding RE. Reality therapy: The Corsini Encyclopedia of Psychology. Hoboken: Wiley 2010:

DOI:

10.1002/9780470479216.corpsy0780

8. Casstevens W. Using reality therapy and choice theory in health and wellness program development within psychiatric psychosocial rehabilitation agencies. Int J Choice Theory Real Therapy. 2010; 29(2):55-8.

9. Farmani F, Taghavi H, Fatemi A, Safavi S. The efficacy of group reality therapy on reducing stress, anxiety and depression in patients with multiple sclerosis (MS). IJABS. 2015; 2(4):338. DOI: $10.22037 /$ ijabs.v2i4.11421
10. Ros-Morente A ,Mora CA, Nadal CT, Belled $A B$, Berenguer NJ. An examination of the relationship between emotional intelligence, positive affect and character strengths and virtues. An Psicol /Ann Psychol. 2018; 34(1):63-7. DOI: 10.6018/analesps.34.1.262891

11. Leaviss J, Uttley L. Psychotherapeutic benefits of compassion-focused therapy: An early systematic review. Psychol Med. 2015; 45(5):927-45. $10.1017 / \mathrm{S} 0033291714002141$

12. Ashworth F, Gracey F, Gilbert P. Compassion focused therapy after traumatic brain injury: Theoretical foundations and a case illustration. Brain Impair. 2011; 12:128-39. DOI: 10.1375 /brim.12.2.128

13. Albertson ER, Neff KD, Dill-Shackleford KE. Self-compassion and body dissatisfaction in women: A randomized controlled trial of a brief meditation intervention. Mindfulness. 2015; 6(3):444-54. DOI: 10.1007/s12671-014-0277-3

14. Gonzalez-Hernandez E, Romero R, Campos D, Burychka D, Diego-Pedro R, Baños R, et al. Cognitively-based compassion training $(\mathrm{CBCT} \AA)$ in breast cancer survivors: A randomized clinical trial study. Integr Cancer Ther. 2018; 17(3):684-96. DOI: $10.1177 / 1534735418772095$.

15. Allen AB, Leary MR. Self-Compassion, stress, and coping. Social and personality psychology compass. Soc Personal Psychol Compass. 2010; 4(2):107-18. $\quad$ DOI: $\quad 10.1111 / \mathrm{j} .1751-$ 9004.2009.00246.x

16. Nery-Hurwit M, Yun J, Ebbeck V. Examining the roles of self-compassion and resilience on health-related quality of life for individuals with Multiple Sclerosis. Disabil Health J. 2018; 11(2):256-61. DOI: 10.1016/j.dhjo.2017.10.010

17. Salimi A, Arsalandeh F, Zahrakar K, Davarniya $R$, Shakarami M. The effectiveness of compassion-focused therapy on mental health of women with multiple sclerosis. Horizon Med Sci. 2018; 24(2):125-31. [Persian]

18. Ghator Z, Pouryahya S, Davarniya R, Salimi A, Shakarami M. The effect of compassionfocused therapy (CFT) on resiliency of women with multiple sclerosis (MS). Armaghane Danesh. 2018; 23(3):350-63. [Persian] 
19. Bandura A. Perceived self-efficacy in cognitive development and functioning. Educ Psychol. 1993; 28(2):117-48. DOI: $10.1207 / \mathrm{s} 15326985 \mathrm{ep} 28023$

20. Caprara GV, Pastorelli C, Regalia C, Scabini E, Bandura A. Impact of adolescents' filial selfefficacy on quality of family functioning and satisfaction. J Res Adolesc. 2005; 15(1):71-97. DOI: $10.1111 / \mathrm{j} .1532-7795.2005 .00087 . \mathrm{x}$

21. Galla BM, Wood JJ, Tsukayama E, Har K, Chiu AW, Langer DA. A longitudinal multilevel model analysis of the within-person and between-person effect of effortful engagement and academic self-efficacy on academic performance. J Sch Psychol. 2014; 52(3):295308. DOI: $10.1016 /$ j.jsp.2014.04.001

22. Schnell K, Ringeisen $\mathrm{T}$, Raufelder $\mathrm{D}$, Rohrmann S. The impact of adolescents' selfefficacy and self-regulated goal attainment processes on school performance: Do gender and test anxiety matter? Learn Individ Differ. 2015; $\quad 38: 90-8$. $\quad$ DOI: 10.1016/j.lindif.2014.12.008

23. Talsma K, Schüz B, Schwarzer R, Norris K. I believe, therefore I achieve (and vice versa): A meta-analytic cross-lagged panel analysis of self-efficacy and academic performance. Learn Individ Differ. 2018; 61:136-50. DOI: 10.1016/j.lindif.2017.11.015

24. Smeets E, Neff K, Alberts H, Peters M. Meeting suffering with kindness: Effects of a brief self-compassion intervention for female college students. J Clin Psychol. 2014; 70(9):794-807. DOI: $10.1002 /$ jclp.22076

25. Gow JE. Reality therapy: A new approach to psychiatry", by William Glasser (Book Review). Et Cetera. 1970; 27:112.

26. Ghoreishi M, Behboodi M. Effectiveness of group reality therapy on emotion regulation and academic self-efficacy of female students. Commonity Health. 2017; 4(3):238-49. [Persian]

27. Ghadampour E, Mansouri L. The effectiveness of compassion focused therapy on increasing optimism and self-compassion in female students with generalized anxiety disorder. PSYS. 2018; 14(1):59-74. [Persian] DOI: 10.22051/PSY.2017.13705.1329

28. Kakia L. Effect of group counseling based on reality therapy on identity crisis in students of guidance schools. JFMH. 2010; 12(45):7-430. DOI: 10.22038/JFMH.2010.1121

29. Gilbert P. Introducing compassion-focused therapy. Adv Psychiatr Treat. 2009; 15(3):199. DOI: 10.1192/apt.bp.107.005264

30. Gorbanalipour M, Najafi M, Alirezalo Z, Nasimi M. The effectiveness of reality therapy on happiness and hope in divorced women. FCPJ. 2014; 4(2):297-317. [Persian] 


\title{
Comparison of the effectiveness of compassion-based therapy and reality therapy on self-efficacy of patients with multiple sclerosis
}

\author{
Golshid Shams $^{1} \quad$ Sara Pashang $^{2^{*}} \quad$ Mastooreh Sedaghat $^{3}$
}

1. Department of Psychology, Kish International Branch, Islamic Azad University, Kish Island, Iran 2. Department of General Psychology, Azad University of Karaj, Karaj, Iran.

3. Department of Psychology, Islamic Azad University of Semnan Branch, Semnan, Iran.

\section{Abstract}

Introduction: The aim of this study was to evaluate and compare the effectiveness of reality therapy and compassion-based therapy on increasing self-efficacy in patients with MS.

Methods : This research was a quasi-experimental study with a pretest-posttest design with a control group. The statistical population included all patients with MS referred to medical centers in Isfahan at 2020, who 45 of them were selected by available sampling method and randomly assigned to experimental and control groups ( $\mathrm{n}=15)$. Scherrer et al.'s (1982) self-efficacy questionnaire was used to collect data and for data analysis, a mixed design with repeated measures was performed by version 26 of SPSS software.

Results: The results showed that the interactive effect of group $\times$ time on the self-efficacy $(\mathrm{F}=91.845)$ was significant $(\mathrm{P}-$ Value $<0.01)$ and compassion therapy and reality therapy significantly affected self-efficacy in the experimental groups. The difference between experimental and control groups in terms of mean of selfefficacy in post-test and follow-up stages compared to pre-test $(\mathrm{F}=6.768)$ was significant $(\mathrm{P}$-value $<0.01)$. These changes in the mean of self-efficacy in the control group in the three stages of the test were not significant. There was no significant difference between the effectiveness of compassion therapy and reality therapy in increasing the self-efficacy of patients with multiple sclerosis $(\mathrm{MD}=3.400, \mathrm{P}-\mathrm{Value}=0.429)$.

Conclusion: Compassion-based therapy and reality therapy can significantly increase self-efficacy in patients with MS; But their effectiveness on increasing self-efficacy is the same.

Keywords: Compassion-Based Therapy, Reality Therapy, Self-Efficacy, MS.

Received: 09 May 2021

Accepted: 03 Feb 2021

How to cite this article: Shams G, Pashang S, Sedaghat M. Comparison of the effectiveness of compassion-based therapy and reality therapy on self-efficacy of patients with multiple sclerosis. Journal of Preventive Medicine. 2021; 8(1).70-80.

Correspondence: Sara Pashang, General Psychology, Azad University of Karaj, Karaj, Iran.

Tel: $09128937996 \quad$ Email: sarahpashang@yahoo.com

ORCID: 0000-0001-6609-3260

(C) 2021 The Author(s). This is an open access article distributed under the terms of the Creative Commons Attribution License (http://creativecommons.org/licenses/by/4.0/), which permits unrestricted use, distribution, and reproduction in any medium, provided the original work is properly cited. 